\title{
THE SOCIALIST LEAGUE LEAFLETS AND MANIFESTOES: AN ANNOTATED CHECKLIST
}

From the formation of the Socialist League on December 30, 1884, until an anarchist take-over forced William Morris from the Commonweal editorship on May 25, 1890, the Council of the League gave a special importance to its pamphlet and leaflet publication. In Commonweal their significance was made quite explicit:

"The Manifesto of the League, the pamphlets in the 'Socialist Platform' series, the leaflets issued by the Council of the League, and articles definitely so stated in the 'Weal, are the only authoritative expositions of the League's creed and policy."'1

After May 25, 1890, notions of "creed and policy" lost force, and - as some late publications show - it rapidly became impossible to identify any corporate responsibility.

But from 1884 to 1890 , the period of the clear Marxist orientation, there is ample documentation, though it is not always clear how and where to consult it. The Manifesto of the League, the larger pamphlets like Morris's The Tables Turned or Thomas Binning's Organized Labour, and the Commonweal articles are all more or less available. There are few problems about their date of publication or authorship. ${ }^{2}$ But the leaflets present several difficulties. Other than Morris's Chants for So-

1 Commonweal, October 27, 1888.

2 There is an exception in the case of the League's Manifesto, which is often attributed solely to Morris but was in fact a joint effort of Morris and E. Belfort Bax, see The Letters of William Morris to His Family and Friends, ed. by Philip Henderson (London, 1950), p. 229. The confusion arises because of a forged "first edition" of the Manifesto produced by Morris's bibliographer, H. Buxton Forman. This has a spurious wrapper on which appears "written by William Morris" in a very prominent position. See H. Buxton Forman's illustration in his The Books of William Morris (London, 1897), p. 115, and Graham Pollard's exposure of the forgery in his introduction to A Catalogue of Books and Pamphlets from the Library of Maurice Buxton Forman [...] Offered for Sale by Bernard Quaritch Ltd. (London, 1973), p. 18. 
cialists none of them indicate their authors' identities; only a few bear dates, and those that do are not always correct.

Many of the leaflets are in the Socialist League Archives at the International Institute of Social History, Amsterdam, ${ }^{1}$ while others are in the British Library, the London School of Economics, and other libraries; but not all the originals have yet been located. Most are flysheets, the most emphemeral kind of publication and the first to be thrown away or used to light the fire. Without a comprehensive listing and description the materials, scattered about in a dozen or more libraries and private collections, have not been as useful as they could be; librarians and scholars have no clear notion of "completeness", and the significance of odd leaflets is easily missed.

What follows is a survey of Socialist League leaflets and manifestoes. Publications already clearly identified and dated are excluded: the Manifesto, the "Socialist Platform" series, the larger, signed pamphlets, and the Commonweal articles. Included are all the leaflets and manifestoes, i.e. leaflets of several pages, which were statements of policy or propaganda of the League. Thus, poetry published by the Council is included as reflecting on policy and as part of the effort to educate the populace in that policy. Leaflets interpreting the Paris Commune and the execution of the Chicago anarchists are included, but documents printed for internal circulation only and those sponsored by individuals or branches are omitted. The checklist is divided into groups of leaflets, such as "Poetry and Music" or "The 'Socialist Leaflets' Series", and the groups are arranged as nearly as possible in chronological order.

All of the leaflets listed were part of the League's official propaganda effort. Taken together with its other publications they show how the League defined its Socialism.

\section{THE "SOCIALIST LEAFLETS" SERIES"}

1. Why Be "Transported?" (No $1 ; \mathrm{BL}$ ).

Date: June 1885 (Commonweal, July 1885, p. 60). Authorship: unknown.

2. "Down with the Socialists!" (No 2; BL).

Date: June 1885 (Commonweal, July 1885, p. 60).

Authorship: Andreas Scheu (the manuscript, in the SLA, is in Scheu's hand).

3. To the Radicals (No 3; LSE).

1 Hereafter SLA. I am especially grateful to Miss M. W. H. Schreuder of the Institute for her help in tracking down several leaflets and publication information. ${ }^{2} \mathrm{~A}$ complete run of this series can be consulted in the SLA. 
Date: August 1885 (Commonweal, September 1885, p. 80).

Authorship: probably William Morris (see his later leaflet For Whom Shall We Vote?, below, item 23, and his article "On the Eve of the Elections": in: Commonweal, December 1885, p. 101).

4. The Cause of Prostitution (No 4; BL).

Date: August 1885 (Commonweal, September 1885, p. 80).

Authorship: probably William Morris or Eleanor Marx-Aveling (see her article on "The 'Pall Mall Gazette"', in: Commonweal, August 1885, pp. 69-70; see also Morris's comments in Letters, op. cit., p. 237, and the reports of the "Meeting on the Recent Exposures", in: Commonweal, September 1885, pp. 78-79. According to the Hammersmith Minute Book, BL, Add. Mss 45891, the League's position was the result of representations made by the Hammersmith Branch, for which Morris naturally did most of the writing.).

5. The Workers' Claims and 'Public Opinion' (No 5; BL).

Date: September 1885 (Commonweal, October 1885, p. 88).

Authorship: Andreas Scheu (Commonweal, September 11, 1886, p. 187. E. P. Thompson, William Morris: Romantic to Revolutionary (London, 1955), p. 465, says this leaflet was "revised by Morris".).

6. Tram-Car Slavery: An Address to Tram-car Men and the Working Class in general (No 6; BL).

Date: September 1885 (Commonweal, October 1885, p. 88).

Authorship: unknown.

7. Home Rule and Humbug. To the Working-People of Great Britain and of Ireland (No 7; BL).

Date: February 1886 ("January, 1886", appears in the imprint, but see Commonweal, February 1886, pp. 12, 16).

Authorship: William Morris (the manuscript, in Morris's hand, is in the Huntingdon Library, HM 6464).

8. The Unemployed and Rioting (No 8).

Date: February 1886 (Commonweal, March 1886, p. 24).

Authorship: probably E. T. Craig (see the Hammersmith Minute Book, entry for February 14, 1886).

9. Shall Ireland be Free? (No 9; BL).

Date: April 1886 (dated in the imprint; see also Commonweal, May 1, 1886, p. 40).

Authorship: probably William Morris (cf. his Home Rule and Humbug, above, item 7, and his article "Independent Ireland", in: Commonweal, May 1, 1886, p. 36).

10. The Socialist Leagu [sic] and Free Speech (No 10; BL).

Date: August 1886 (Commonweal, August 7, 1886; the printing invoice for this leaflet, in the SLA, is dated "29.7.86").

A uthorship: unknown. 
11. What Socialists Want (No 11; 2 pp.; BL).

Date: August 1886 (Commonweal, August 7, 1886, p. 152). In 1888 it was reprinted as a four-page leaflet with two pages of advertisements.

Authorship: William Morris (printed and distributed both by the Hammersmith Branch and the Socialist League Council, this leaflet is the one referred to as having been written by Morris; see Commonweal, May 12, 1888, p. 147, and the Hammersmith Minute Book, entry for January 9, 1887).

\section{TOPICAL FLY-SHEETS}

Unfortunately, at the beginning of 1887 the League stopped issuing its leaflets as a numbered series. To add to our difficulty, the practice also ceased of advertising all new publications by title, and - as was often the case in 1885 and 1886 - announcing each new title in the "To Correspondents" column of Commonweal. Consequently, the fly-sheets of $1887-89$, listed here, are more often obscure in date and authorship. Though I have attempted to place them in chronological order, in several cases that order is based on little more than a guess.

12. Strikes and the Labour Struggle. To those Workmen on Strike for More Pay or Shorter Hours of Labour, and All Those Discontented with their Position (BL and SLA).

Date: January 1887 (Commonweal, January 15, 1887, p. 22).

Authorship: probably Joseph Lane, Chairman of the Socialist League Strike Committee (he read it to the Council for their approval in December 1886, see Commonweal, December 25, 1886, p. 311).

13. Socialists and the Jubilee. A Word on the Class War (BL and SLA).

Date: June 1887 (reprinted from Commonweal, this leaflet appeared, according to E. P. Thompson, op. cit., p. 567, on "Jubilee Day", i.e. June 20, 1887).

Authorship: Frank Kitz (in his "Wimbledon and Merton Notes", in: Commonweal, July 9, 1887, p. 221, Kitz says: "Before entering my train I gave a Jubilee Bill to a burly engineer. After reading a few lines only, he said, 'Whoever wrote that ought to be locked up.' Being the writer a guilty feeling overcame me."). The verso of the BL copy carries Fred Henderson's poem "At the Queen's Jubilee", reprinted from Commonweal, April 9, 1887, p. 115.

14. The Chicago Anarchists. A Brief Statement of the Case (SLA).

Date: September-October 1887 (SLA printing invoice is dated "6.10.87", but correspondence between the Marx-Avelings and the Socialist League Council, see below, indicates that they were being distributed in October). The SLA copy is titled merely A Brief Statement of the Case.

Authorship: Edward and Eleanor Marx-Aveling (see their letter to the Socialist League Council, October 23, 1887, SLA; see also their article "The Chicago Anarchists. A Statement of the Facts", in: To-Day, November 1887). 


\section{The Chicago Martyrs [and] Bloody Sunday (SLA).}

Date: c. November 1, 1888 (the leaflet refers to "Bloody Sunday" as "last Autumn"; the verso of the SLA copy advertises the meeting of the "United Socialist Societies" mentioned in Commonweal, October 20, 1888, p. 239). Authorship: unknown.

16. To Working Women and Girls (SLA).

Date: January 1889 (originally published in Commonweal, December 8, 1888 , p. 389 , this was later issued as a leaflet by the Propaganda Committee of the League; see ibid., January 26, 1889, p. 31). Frank Kitz, see below, says that it was later re-issued by the Social Democratic Federation.

A uthorship: Frank Kitz (the first Commonweal printing is signed by D. J. Nicoll, but Kitz says he drafted it, see his "Recollections and Reflections", in: Freedom, June 1912, p. 42).

17. The Paris Commune, March 18th, 1871 (SLA).

Date: March 1889 (the text begins: "On this day eighteen years ago", and the verso advertises the meeting to be held on March 16).

Authorship: unknown.

18. Labor is the source of all Wealth, therefore all Wealth belongs to the Laborers (SLA).

Date: before May 18, 1889 (listed in Commonweal on that date, p. 160). Reprinted after November 11, 1889, bearing the new Commonweal address, "24 Great Queen St., Lincoln's Inn Fields, W.C."

Authorship: unknown.

19. The Paris Commune, March 18th, 1871 (2 pp.; SLA).

Date: March 1890 (dated in the imprint, the leaflet includes a reference to the Commune as "nineteen years ago"; first printed in Commonweal, March 16, 1889, p. 84).

Authorship: possibly D. J. Nicoll (he signed a note following the Commonweal printing asking for criticism and suggestions for revision before issuing the text as a leaflet).

20. To The Workers (2 pp.; LSE).

Date: before November 11, 1889 (the address given in the imprint, "13 Farringdon Road, London, E.C.", changed on that date; internal evidence suggests sometime in 1888).

Authorship: unknown.

\section{MANIFESTOES}

A third, smaller category of Socialist League Council publication was rather more weighty and usually longer, running to as much as eight pages. Mindful of their greater length and importance, I refer to these all published without an author's name or date - as "manifestoes", but in League literature that term may apply to any of the various leaflets. 
21. To Socialists ( 3 pp.; $\mathrm{BL})$.

Date: January 13, 1885 (printed on the leaflet).

Authorship: ten names are added as having signed this document: Edward Aveling, Eleanor Marx-Aveling, Robert Barnes, E. Belfort Bax, J. Cooper, W. C. Clark, Joseph Lane, S. Mainwaring, J. L. Mahon, William Morris. Delays over disagreements of principle in the earlier drafts suggest that this final printed version was a true collaboration (see E. P. Thompson, op. cit., p. 446).

22. Manifesto of the Socialist League on the Soudan War (4 pp.; BL and SLA).

Date: March 1, 1885 (Commonweal, March 1885, p. 12; April, p. 20). Authorship: Ernest Belfort Bax (though the printed version is signed by twenty-three members of the League's Provisional Council, the manuscript, in the SLA, is in Bax's hand; see also his article "Gordon and the Soudan", in: Commonweal, March 1885, p. 9).

23. For Whom Shall We Vote? Addressed to the Working-Men Electors of Great Britain (8 pp.; BL and SLA).

Date: November 1885 (dated so on the leaflet).

Authorship: William Morris (though signed "The Council of the Socialist League", this leaflet was the subject of correspondence between Morris, as author, and the League Council Chairman, November 9, [1885,] in the SLA).

24. Payment of Labour in the Socialistic State (4 pp.; SLA).

Date: between December 1885 and February 1886 (as indicated on the leaflet, the text was first published in Commonweal, December 1885, p. 103; advertisements on the SLA copy were published only in the interval given here).

Authorship: J. H. Smith.

25. A Straight Talk to Working-Men (4 pp.; SLA).

Date: February 1889 (Commonweal, February 2, 1889, p. 39; this text appeared ibid., February 23, p. 60).

Authorship: H. B. Samuels.

26. The Chicago Martyrs ( 3 pp.; SLA).

Date: c. November 1889 (the text, as "The Chicago Murders", first appeared in Commonweal, October 26, 1889, p. 340, where orders are solicited for the leaflet to be published).

Autorship: D. J. Nicoll.

\section{POETRY AND MUSIC}

27. Chants for Socialists (BL).

Date: there are three authorized editions and several reprints of this leaflet. The first edition ( 8 pp. + wrapper), published by Reeves for the Democratic Federation early in 1884 , contained only one poem, "The Day Is 
Coming". The second (16 pp.), with the Socialist League imprint, appeared between February and May 1885, and contained six poems. The League published a third edition (16 pp.) later in 1885 (see the imprint and Commonweal, June 26, 1886, p. 103). This included a seventh poem, "Down Among the Dead Men". Reprints of this edition were issued in 1885 and again in 1892, after Morris had left the League. Graham Pollard recently identified a forged "edition" of this leaflet, produced by Morris's bibliographer, containing only two poems: "All for the Cause" and "The Day is Coming" (see above, p. 21, note 2).

Authorship: William Morris.

28. Songs for the People ( 1 p.; SLA).

Date: probably 1887 (the SLA copy advertises a lecture for May 2, 1887, and one poem, "Red, White, and Blue", has an inserted reference to the Irish question, which was the occasion for some united action of Socialists, Radicals and Irish in that year).

Authorship: one of the three poems is reprinted from the Boston Globe, but all are anonymous.

29. At the Queen's Jubilee (1 p.; BL).

Date and Authorship: see above, item 13.

30. All for the Cause (4 pp.; SLA).

Date: 1887 (first advertised on the wrapper of Nupkins Awakened, a pamphlet published in October 1887; see Commonweal, October 22, 1887, p. 343).

Authorship: words by William Morris, music by E. Belfort Bax.

31. A Death Song (8 pp. with prefatory matter; BL).

Date: published to be sung at the funeral of Alfred Linnell, December 18 , 1887 (Commonweal, December 24, 1887, p. 413).

Authorship: words by William Morris, music by Malcolm Lawson.

32. Songs for the Workers ( 1 p.; SLA).

Date: first advertised in Commonweal, May 18, 1889, p. 140 . Reprinted after November 16, 1889, when the Commonweal address changed to 24 Great Queen Street.

A uthorship: there are two poems, "Song of the 'Lower' Classes", by Ernest Jones, and "Marseillaise", by Rouget de Lisle.

33. The Starvation Army (1 p.; SLA).

Date: see above, item 32.

Authorship: unknown.

34. Songs for the Workers (2 pp.; SLA).

Date: first advertised in Commonweal, November 9, 1889, p. 353.

Authorship: there are two poems: "Our Old Men in the Street", by Fannie S. Roper (reprinted from Twentieth Century), and "Lyric of Labour", by Venier Voldo (reprinted from Integral Co-operator of Grass Valley, California). 


\section{LEAFLETS ADVERTISED}

All the leaflets listed above are available in the collections specified after each title. But besides these there were several published for which copies have not yet been located. They are as follows:

35. Echoes of the Coming Day, Socialist Songs and Rhymes (16 pp.).

Date: first advertised in Commonweal, July 30, 1887, p. 248. The printing invoice (SLA) is dated "28.7.87".

Authorship: Fred Henderson.

36. The Unemployed Question.

Date: first published in Commonweal, as "The Unemployed" (October 29, 1887, pp. 348-49), this text was later issued as a leaflet.

Authorship: though the leaflet is signed "H. A. Barker for the Council" (Barker was elected secretary of the League at the meeting of December 20, 1886), the Commonweal article was by William Morris (see The Report of the Fourth Annual Conference of the Socialist League).

37. The Doctrine of the Communists (2 leaflets, 1 p. each).

Date: first advertised in Commonweal, May 18, 1889, p. 140.

Authorship: unknown.

38. Ireland a Nation (1 p.).

Date and Authorship: as above, item 37.

39. The Liberty and Property Defence League ( 1 p.).

Date and Authorship: as above, item 37.

A final word of caution on the limitations of this checklist. It does not include any detailed study of leaflets produced by branches, either as policy manifestoes or propaganda relating to local issues. The Glasgow Branch of the Scottish Land and Labour League (the Scottish Section of the Socialist League) produced at least two: Manifesto of the Glasgow Branch of the Socialist League to the People of Scotland (1887) and to the Men and Women of the Working Class (1885). ${ }^{1}$ The Birmingham Branch issued one, of which a copy is in the London School of Economics, on the Midland Railway Strike of 1886. The Hammersmith Branch published many, including its founding manifesto, originally written by Morris during Social Democratic Federation days of 1884. From the Dublin Branch came one, now in the British Library, on the relation of Home Rule and Socialism. There are undoubtedly many more of these which a search of provincial libraries would turn up, but they are not policy statements of the Council and therefore fall outside our scope.

1 See E. P. Thompson, op. cit., pp. 514, 562. 
For somewhat different reasons - because of the difficulty of defining "policy" at all - leaflets published after May 25, 1890, are excluded. One example here would be Frank Kitz's The Land for the People. Are we Over-populated? "A useful leaflet, full of facts", according to the advertisement in Commonweal. ${ }^{1}$ Another is Regard the German Emperor, issued in $1891 .{ }^{2}$ Nor can this list give much detail of the many printed leaflets, circulars, cartoons, etc., which served as communication between branches and between the various committees and their individual members. ${ }^{3}$ Obviously all these materials have their bearing as documents relating to the history of English Socialism, but the material published by the Socialist League Council has a special importance and should be properly assembled and identified. There may now be a sufficiently strong case for reprinting it with the necessary editorial apparatus.

1 August 9, 1890, p. 256.

${ }^{2}$ First advertised in Commonweal, July 11, 1891, p. 74.

${ }^{3}$ Two of these - one signed by Thomas Bolas and titled Parliamentarianism in the Socialist League, and another by Joseph Lane headed To the Members of the Socialist League - are in the SLA. Others are mentioned by E. P. Thompson, op. cit., pp. 596, 598. 